\title{
Test of anthocyanin level and evaluation of rambutan leaf extract (nephelium lappacheum L.) as an alternative to disclosing agent of dental plaque detection solution
}

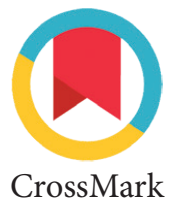

\author{
Asti P. Adnan, Siti Z. Tripalu, Erwin Gunawan*, \\ Ahmad S. Jarigau, Rini Pratiwi
}

Abstract

Objective: This aspects influenced researchers to make disclosing materials of natural-based solution can be obtained from the bark of rambutan (nephelium lappaceum L.) containing anthocyanins that can be used to detect dental plaque

Material and Methods: Undertaken consisted of testing the Results: Rambutan leaf extract has flavonoid compounds in the form determination of the levels of anthocyanin with pH Differensial of anthocyanin compounds that is safe for the body and can be used as methods, test the determination of content the total phenolic with dental plaque detection.

method folin-ciocalteu, test the determination of the activity catcher free radical DPPH and qualitative analysis of flavonoids in order to prove the existence one of flavonoid compounds, namely in the form of anthocyanin compounds. In addition, researcher do toxicity test and detection of the plaque. This is done to know the rambutan leaf extract can be safely used by the public and can be used as dental plaque detection.

Conclusion: Rambutan leaf based disclosing solution may effective for detecting dental plaque.

Keywords: Anthocyanins, Disclosing sulution, Plaque

Cite This Article: Adnan AP, Tripalu SZ, Gunawan E, Jarigau AS, Pratiwi R. 2019. Test of anthocyanin level and evaluation of rambutan leaf extract (nephelium lappacheum L.) as an alternative to disclosing material of dental plaque detection solution. Journal of Dentomaxillofacial Science 4(1): 3-6. D0I: 10.15562/jdmfs.v4i1.540

Department of Dental Public Health, Faculty of Dentistry, Hasanuddin University, Makassar, Indonesia
*Correspondence to: Erwin Gunawan, Faculty of Dentistry, Hasanuddin University, Makassar, Indonesia erwingunawan394@gmail.com

Received: 5 August 2017 Revised: 26 February 2019 Accepted: 28 February 2019 Available Online: 1 April 2019

\section{Introduction}

Dental hygiene looks at how much plaque that stick of teeth. Clinically, the plaque visible on the surface of the teeth along the margins of the gingiva is commonly called dentogingiva plaque. ${ }^{1}$ In addition, plaque can also be found under gingival margin in the gingiva or sulcus in the poket periodontal commonly referred to as subgingival plaque. Plaque is closely attached to the deposit on the surface of teeth or other solid surface in the mouth as in the restoration of the cekat as well as spin-off so it is not easily removed by rinsing with water. ${ }^{2}$ Plaque was instrumental in the process of occurrence of caries so that the presence of plaque in the cavity of the mouth shows the person's level of oral hygiene.

Plaque control efforts can be done in two ways, mechanically and chemically. Controlling plaque mechanically is a pretty good method to control plaque that is either a tooth brushing and the use of dental floss. This is because the control of plaque mechanically psychomotor in nature from the patient and proved effective when done on a regular basis. In addition, the control of these plaques often do not provide the most because it can interfere - with the health of gingival plaque control is also done so that is chemically like toothpaste as a means of supporting the control of plaque. ${ }^{3}$ Toothpaste serves to reduce the formation of plaque, cleans the surface of the teeth, providing a fresh flavor and eliminate bad breath. ${ }^{4}$ But less community awareness in controlling plaque that can lead to the occurrence of caries. Therefore, the community needs to be detected early by using plaque disclosing solution so that it can control maximum plaque and prevent the occurrence of caries.

Rambutan is one of the many plants cultivated in Indonesia. Its still untapped red creature. The existence of a deep red color pigment anthocyanin that there is thought to be used as a natural dye. ${ }^{5}$ Therefore, to reduce environmental pollution waste treatment can be done then skin herbs it into a material that can be reused. One of them is the subject of disclosing solution to detect dental plaque. By using or disclosing the substance of coloring can tell patients the presence of plaque and can indicate the level of hygiene of the teeth brushing results he has done. ${ }^{6}$ 


\section{Material and Methods}

This research was conducted in the laboratory of pharmaceutical unhas. The subject study was the male mice are applied topically by rambutan leaf extract solution on the mice teeth. Before doing the research, researchers preparing tools and materials like glass, ${ }^{7}$ stir bar blender, bottle chemical bottle, vial, bowls glass funnel, porcelain, plastic funnel, ELISA Reader, measuring cup, herbs, pumpkin dryer tentukur $5 \mathrm{~mL}$, hood, Bowl, mikropipet, microplate, $\mathrm{pH}$ test paper Nesco, dropper drops, plates, spoon the Rotary evaporator, horns, $\mathrm{KCl}$, aquadest, potassium acetate, $\mathrm{HCl}$ solution $0.2 \mathrm{~N}$, UV-Vis spectrophotometer, ${ }^{7,8}$ measuring jug, talang, analytic scales, jar, $\mathrm{Na} 2 \mathrm{CO} 3$, well plate, folin reagent-ciocalteu's $50 \%$, aluminum foil error, acid, citric acid, $\mathrm{pH}$ buffer, biscuits, capillary tube heparine, cotton bud, DPPH (1.1-diphenyl-2-2-pikrilhidrazil), ${ }^{8}$ label paper, filter paper, paper weigh, rambutan's skin that's been washed and concentrated ammonia solution, blended, 14 male mice tails, methanol, methanol with p. technically, microtest tube $1.5 \mathrm{~mL}, \mathrm{NaCMC}$, ${ }^{9}$ disclosing product solution eritrosin, phenols and tissue. Preparing the tools and materials, we conducted a test of the determination of the levels of anthocyanin with $\mathrm{pH}$ Differensial methods, test the determination of the total content of phenolic folin-ciocalteu method, test the determination of the activity of the free radical DPPH catcher and qualitative analysis of flavonoids in order to prove the existence of one flavonoid compounds, namely in the form of anthocyanin compounds. Having proved that there is content of the relationships, the authors tested the toxicity test and detection of the plaque. This is done to know the leaf extract of herbs can be safely used by the public and can be used as dental plaque detectionn.

\section{Data Collection and Analysis}

The data generated in this study were analyzed statistically, the average value of the maximum wave

\section{Table 1 The average value of absorban pH 1 and pH 4.5}

\begin{tabular}{lcccc}
\hline \multirow{2}{*}{ Sample ID } & \multicolumn{2}{c}{ The Wavelength (nm) } & \multicolumn{2}{c}{$\begin{array}{c}\text { Means of The Wavelength } \\
\text { (nm) }\end{array}$} \\
\cline { 2 - 5 } & 511.5 & 779 & 511.5 & 779 \\
\hline $\mathrm{pH} \mathrm{1}$ & 0.736 & 0.009 & 0.748 & 0.005 \\
& 0.743 & 0.002 & & \\
& 0.766 & 0.005 & & \\
& & & & \\
$\mathrm{pH} 4.5$ & 0.293 & 0.010 & 0.313 & \\
& 0.317 & 0.019 & & \\
& 0.329 & 0.019 & & \\
\end{tabular}

length of absorban situated at a wavelength of $511.5 \mathrm{~nm}$ with a minimum of 3 times the replication. After that, the IC50 value calculations are performed, i.e. the concentration of extract which generates 50 barriers\% against DPPH of $42.609 \mu \mathrm{g} / \mathrm{ml}$ based on raw curve between the concentration of extract and percent of rambutan's skin barriers DPPH. Based on the analysis of the total phenolic content, obtained the average levels of polyphenols on the concentration ppm samples used i.e. $13.66 \%$ based on raw curve between concentration ppm skin extract rambutan and concentration of aqueous acid standard error. The results obtained is inversely proportional to the activity of the antioksidannya which give greater results with a concentration of $20 \mathrm{ppm}$ i.e. of $26.916 \%$. It allegedly caused rambutan fruit skin contains compounds that are potent antioxidant phenolic compounds in addition. One compound that have antioxidant activity beside phenolic are anthocyanin.

\section{Results}

This research was conducted for over 1 month, starting from late May to mid-July. The first stage, namely the extraction of rambutan's skin. The extraction was done using the method of maceration with the methanol solvent was technical. The results of the extraction were then evaporated through the Rotary evaporator to extract obtained. Furthermore this viscous extract was dried again at light-proofed room and a cold room temperature so that the dry extract was obtained as much as 22.2612 grams. The result of the dry extract was used in testing the levels of anthocyanin, the levels of polyphenols, capture free radicals activity and qualitative analysis of flavonoids.

Based on table 1, the wavelength of maximum derived on measurement results of rambutan's Skin maceration extract of $511.5 \mathrm{~nm}$. According to Harborne, relationships have a range of regional spectrum looks at $475-550 \mathrm{~nm}$. This shows that the extract Skin maceration results contain anthocyanin rambutan. In a State approaching $\mathrm{pH}$ 1.0 more anthocyanin pigments are in the form of flavilium or oxonium cation that was colored and measuring absorbance will show the number of relationships that were getting bigger. Whereas the $\mathrm{pH}$ of a weak acid 4.5 cation flavilium changed into a more stable form hemiketals or colorless carbinols and kalkon. Based on the average length of the wave, retrieved $16.57 \%$ percent content of anthocyanin extract dry skin on the rambutan.

On the determination of the total content of phenolic acids in raw error curve made as blanko 


\section{The gallic acid standard curve}

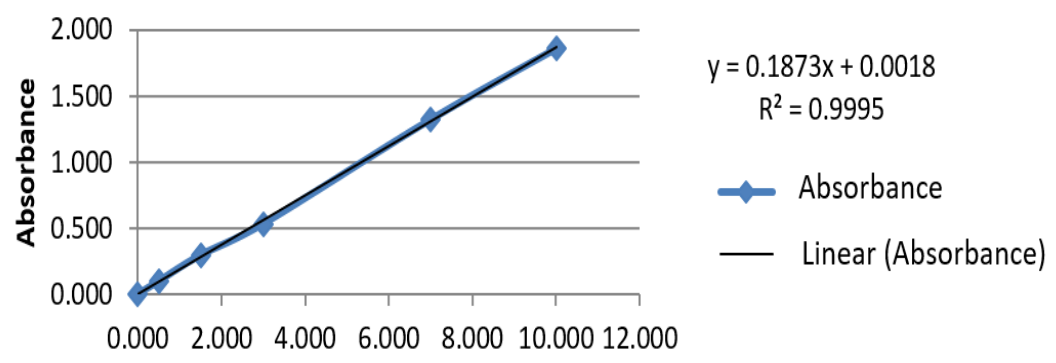

Concentration

Figure 1 Raw curve acid error

Table 2 The activity of catching free radicals

\begin{tabular}{cc}
\hline Concentration & percent inhibition \\
\hline 10 & 15.347 \\
20 & 26.916 \\
30 & 37.657 \\
40 & 47.361 \\
50 & 57.216 \\
\hline
\end{tabular}

\section{Regression Curve}

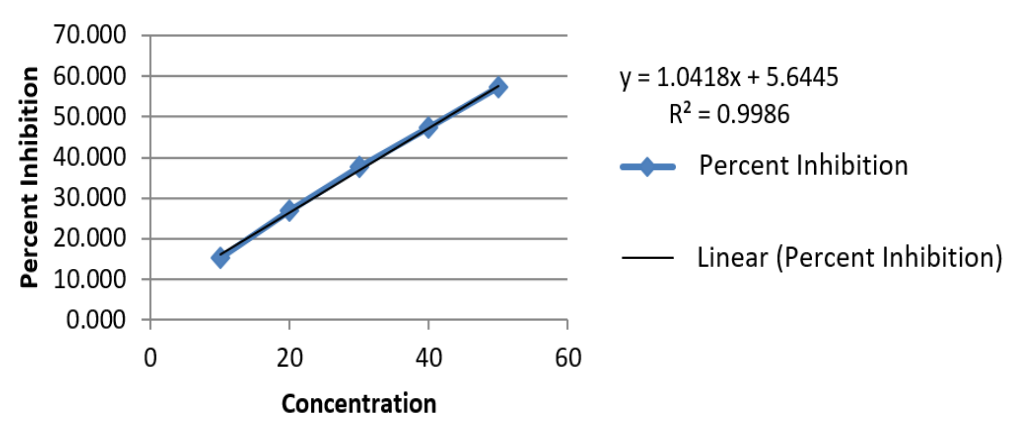

Figure 2 The regression curve inhibition of antioxidants

consists of error acid $0.5 \mathrm{ppm}, 1.5 \mathrm{ppm}, 3 \mathrm{ppm}$, $7 \mathrm{ppm}$ and $10 \mathrm{ppm}$. The results obtained are incorporated into the raw curve error acid so obtained results correlation coefficient i.e. 0.9995. The curve can be seen in figure 1 . On the raw curve error acid, increasing the value of the concentration of the standard solution then it will increase the value of absorbance. Then to measure the levels of polyphenol concentration ppm samples used, namely $20 \mathrm{ppm}$ in order to get maximum levels of polyphenols. On the levels of polyphenols i.e. KR1 $12.95 \%$, KR 2 KR $14.38 \%$ and IE 3 i.e. 13.64\%. median levels average gained $13.66 \%$ IE.

On determination of the activity of free radical DPPH used arrest and concentration of sample that is $10 \mathrm{ppm} 20 \mathrm{ppm}, 30 \mathrm{ppm}, 40 \mathrm{ppm}$ and 50 $\mathrm{ppm}$. The results obtained, namely the higher concentration ppm then the higher power drag free

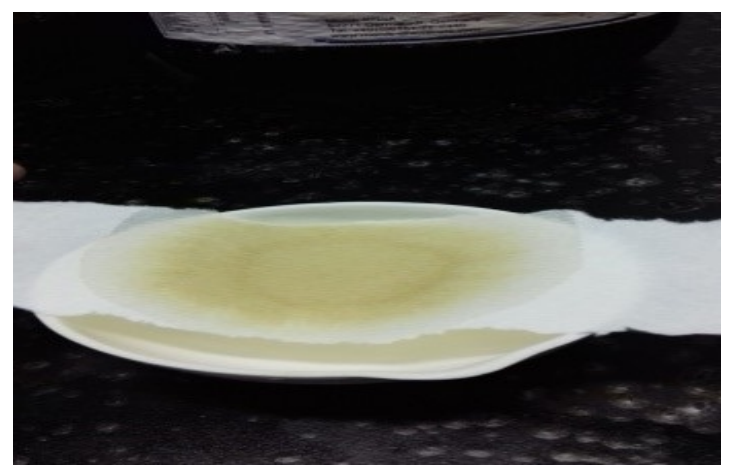

Figure 3 Compounds of flavonoids from leaf extracts of rambutan

radicals. The results can be seen in table 2 . Table 2 showed the concentration of $20 \mathrm{ppm}$ on the determination of antioxidant that is $26.916 \%$. The results obtained in the inversely proportional to the concentration of $20 \mathrm{ppm}$ has a total median-median levels of polyphenols is just $13.66 \%$. It allegedly caused skin rambutan contains compounds which are potentially as an antioxidant in addition to phenolic compounds. One of the compounds that have antioxidant activity in addition to phenolic compounds are compounds of anthocyanin. The results of the percent inhibition of then put into the regression curve. The curve can be seen in figure 2 .

Based on figure 2, the value of the linear regression equation are obtained and the values of IC50 rambutan's skin extracts, namely 42,609 $\mu \mathrm{g} / \mathrm{ml}$. Values of IC50 indicates that sample extracts of the bark has a strong antioxidant rambutan.

Qualitative analysis on the determination of flavonoid skin sample extract, rambutan was declared positive contains flavonoids compounds due to change in color from pale yellow filter paper into intensive yellow. The results can be seen in figure 3.

Based on table 3 , test toxicity after administered skin extract rambutan orally $1 \times 24$ hours obtained observations that are not found the presence of dead mice. In addition, for 3 consecutive days of mice experienced weight gain and keep your activities.

In table 4 , the test results obtained on the detection of plaques that occur after the discoloration of the teeth topically applied skin extract solution of rambutan. The higher the concentration of aqueous extract of rambutan's skin, the color change on teeth mice become more clear. The following is a table of the results of observations of the discoloration of the teeth of mice on a time interval of 5, 15, 25, 35, 45, 55 seconds. 
Table 3 The murine body weight measurement

\begin{tabular}{rccc}
\hline Group & Day 1 & Day 2 & Day 3 \\
\hline Group 1 & & & \\
Mice 1 & $27.2 \mathrm{~g}$ & $28.1 \mathrm{~g}$ & $28.5 \mathrm{~g}$ \\
Mice 2 & $20.9 \mathrm{~g}$ & $21 \mathrm{~g}$ & $22 \mathrm{~g}$ \\
Mice 3 & $32.7 \mathrm{~g}$ & $33 \mathrm{~g}$ & $33.5 \mathrm{~g}$ \\
Mice 4 & $23.5 \mathrm{~g}$ & $24.4 \mathrm{~g}$ & $25.5 \mathrm{~g}$ \\
Group 2 & & & \\
Mice 1 & $18.7 \mathrm{~g}$ & $19.6 \mathrm{~g}$ & $20.4 \mathrm{~g}$ \\
Mice 2 & $17.9 \mathrm{~g}$ & $18.9 \mathrm{~g}$ & $20.2 \mathrm{~g}$ \\
Mice 3 & $17.5 \mathrm{~g}$ & $19.1 \mathrm{~g}$ & $19.4 \mathrm{~g}$ \\
Mice 4 & $19.0 \mathrm{~g}$ & $21.2 \mathrm{~g}$ & $21.8 \mathrm{~g}$ \\
Group 3 & & & \\
Mice 1 & $17.5 \mathrm{~g}$ & $19.0 \mathrm{~g}$ & $20.0 \mathrm{~g}$ \\
Mice 2 & $16.1 \mathrm{~g}$ & $16.9 \mathrm{~g}$ & $17.6 \mathrm{~g}$ \\
Mice 3 & $17.5 \mathrm{~g}$ & $19.3 \mathrm{~g}$ & $20.8 \mathrm{~g}$ \\
Mice 4 & $16.9 \mathrm{~g}$ & $17.5 \mathrm{~g}$ & $19.3 \mathrm{~g}$ \\
Group 4 & & & \\
Mice 1 & $15.5 \mathrm{~g}$ & $16 \mathrm{~g}$ & $16.8 \mathrm{~g}$ \\
Mice 2 & $18.5 \mathrm{~g}$ & $19.1 \mathrm{~g}$ & $21.2 \mathrm{~g}$ \\
\hline
\end{tabular}

Table 4 The results of observations of the discoloration of the teeth of mice

\begin{tabular}{llllllll}
\hline & \multicolumn{3}{c}{ Time (second) } & \multicolumn{3}{c}{ Interval (second) } \\
\cline { 2 - 7 } & $\mathbf{5}$ & $\mathbf{1 5}$ & $\mathbf{2 5}$ & $\mathbf{3 5}$ & $\mathbf{4 5}$ & $\mathbf{5 5}$ \\
\hline $50 \%$ rambutan's leaf extract & + & + & + & + & + & \\
& + & & & & & \\
$75 \%$ rambutan's leaf extract & & + & ++ & ++ & ++ & ++ \\
$100 \%$ rambutan's leaf extract & + & & & & & & \\
Disclosing solution & +++ & +++ & +++ & +++ & +++ & +++ \\
\hline
\end{tabular}

Assessment Criteria : $(+)$ Yellow $=33,67$

$(++)$ Orange $=33,67-66,67$

$(+++)$ Red $=66,67-100$

\section{Discussion}

Levels of anthocyanin obtained in this study i.e. $16.57 \%$ on dried skin extract rambutan. The results obtained were very much different from the previous study is $55.76 \%{ }^{10}$ One that causes the difference in levels of anthocyanin is taking place of rambutan's skin and the difference in solvent is used. In addition, the purpose of use of the levels of anthocyanin from previous research as natural dyes so test against toxicityand use of plaque detection is not done. This study has been carried out testing and testing of toxicity as a natural tooth plaque detector and get positive results of its use on the teeth.

\section{Conclusion}

Rambutan's leaf extracts contain anthocyanin compounds that is safe for the body and can be used as dental plaque detection.

\section{Acknowledgment}

Thank you for the Faculty of Dentistry Hasanuddin University, which has been very supportive of this research.

\section{Conflict of Interest}

The authors report no conflict of interest.

\section{References}

1. Menon L, Ramamurthy J. New vistas in plaque control. IOSR J Dent \& Med Sci 2014;13: 64

2. Carranza EA, Newman MG. Clinical periodontology. 9th ed. Philadelphia: W.B. Saunders; 2002. p. 76.

3. Pannuti CM, Mattos JP, Ranoya PN, et al. Clinical effect of a herbal dentifrice on the control of plaque and gingivitis. Pesqui Odontol Bras 2003;17: 314-315.

4. Forward GC, James AH, Barnet P. Gum health product formulation. Periodontol 2000;15: 32-39.

5. Siahaan LO, Hutapea ERF, Tambun R. Ekstraksi pigmen antosianin dari kulit rambutan (Nephelium lappaceum) dengan pelarut etanol. J Teknik Kimia USU 2014;3: 32.

6. Ekoningtyas EA, Triwiyatini, Nisa F. Potensi kandungan kimiawi dari ubi jalar ungu (Ipomoea Batatas L) sebagai bahan identifikasi keberadaan plak pada permukaan gigi. J Kesehatan Gigi 2016;3: 2.

7. Suzery M, Lestari S, Cahyono B. Penentuan total antosianin dari kelopak bunga rosella (Hibiscus sabdariffa L.) dengan metode maserasi dan sokshletasi. JSM 2010;18: 1-6.

8. Ismail. J, Runtuwene MRJ, Fatimah F. Penentuan total fenolik dan uji aktivitas antioksidan pada biji dan kulit buah pinang yaki (Areca vestiaria Giseke). Jurnal Ilmiah Sains 2012;12: 84-88.

9. Sari F, Nurkhasanah, Bachri MS. Uji toksisitas akut ekstrak etanol kelopak rosella (Hibiscus sabdariffa L.) pada tikus sprague dawley. Trad Med J 2016;21: 12-18.

10. Hutapea ERF, Siahaan LO, Tambun R. Ekstraksi pigmen antosianin dari kulit rambutan (Nephelium lappaceum) dengan pelarut metanol. J Teknik Kimia USU 2014;3: 34

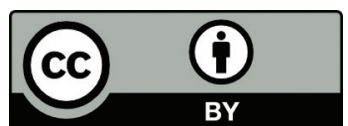

This work is licensed under a Creative Commons Attribution 